UDC: $331.7(575.1)$

DOI: $10.24044 / \mathrm{sph} .2017 .4 .47$

\title{
TECHNOLOGIES OF MAKING OFFICIALS' ACTIVITIES EFFECTIVELY IN STATE SERVICE
}

J. K. Yusubov

\author{
Reseacher,e-mail: jamshid_yusupov@mail.ru, \\ National University of Uzbekistan \\ named after Mirzo Ulugbek, \\ Tashkent, Uzbekistan
}

\begin{abstract}
In the relationship of officials can make a good impression among staffs with the help of 5 means; to make conversation sincerely; to encourage staffs; to persuade staffs; to criticize sincerely: to boast them sincerely. Most officials can't manage governing in proper way and in achieving their goals in order not to lose their positions they damage to others, organization, sometimes even to the state and of course they try to hide their actions and disguise and such attitude make economic, spiritual damage to people and state. Opinions about some principles of officials recognized by the world, technologies on officials' features and making effective relations in proper way in management are given in this article.
\end{abstract}

Keywords: public administration; public service; head; control system; stages of formation of government.

After gaining independence of our country many changes occurred in different aspects of social, political, spiritual - educational and economic spheres. The problems of staffs play important role In harmonizing measures on developing and improving these spheres with national progress. So training state staffs to be loyal to the motherland, to be social active, experienced and spiritual specialists is considered one of the important tasks of our state and society. Especially, it is important for officials to be responsible and to approach critically to their work. As the president of our country Sh. Mirziyoev mentioned "critical analysis, strong discipline and personal responsibility should be daily rule of each officials - whether they will be Prime Minister or his deputies, the number of the government or hakims of the region" $[1, \mathrm{p}$. 6]. His words shows that how it is important and actual.

Loyalty of the employees serving for the government and his knowledge as well as skills are formed in accordance with the system of the organization administration. But falsified manifestation of strict administration and requiring the results which are impossible to get will cause the employee to have positive attitude and results of the working activity. But if there is indifferent attitude to the requirements of the administration, this way the administrator works will negatively influence on the employee, in this case the discipline levels and their compliance will decrease in efficiency, there will be slower rates in the loyalty to commitments of the employees and administrators, the willing to invent will fade in their hearts. The level of the knowledge the employee has will become quite stable. Stability is the real enemy of the organization development. In order to tackle these problems any organization should have own technologies of selecting employees and training. This technology should be based on the general principles: leadership, planning, making decisions, developing, executing, regulating, controlling, assessing, taking measures.

The organization and its employees following all these principles will have effective and progressive results in their working activity, the more they develop on the basis of these principles, the more their competence levels will increase.

Correct way of attitude is the real component of the human spirituality. Misunderstanding and mutual disagreements between the individuals referring to groups ranging from ordinary citizens to the prominent celebrities, or between the small 
groups as well as big corporations will probably lead to scandals, big contrasts and even wars. This eventuality will prompt any individual to try to perceive the personality and attitude as well as psychology he is going to have conversation with, basically for individuals serving for the government. Generally saying, perception of the person, his personality and the way he thinks will serve as a factor to perceive a partner taking into account the way he thinks and lives. It means, an administrator should understand his employees as well as he understands himself [2, p. 15-16]. These misunderstandings, the fact that administrators do not understand his employees and their personality will lead to failures in finding solutions to the biggest problems of the society, it may also cause these problems to less provision of peaceful life in the country [3, p. 226].

Certainly any administrators wishes to have positive conclusion of the attitudes, he has a willing to have positive effect for solution of the problems, but for that he must imagine himself in shoes of the people he is communicating with, he must not consider himself as a person to solve the problem, but he must behave like a person who needs for help, modest and reliable, only in this case management can be counted as perfect.

In our president Sh. Mirziyoev's order "The conception about ratifying administrative reforms in the republic of Uzbekistan" defined exactly that officials should know their work and duties well [4].

There are five factors by means of which administrator or the manager cann make adequate impression on the employees: having a sincere conversation, cheering the employee up; persuading the employee; ability to sincerely criticise; ability to sincerely praise.

The manager or the administrator starting to communicate will have to take into consideration the character and behavior norms of the people around.But people can have variety of characters, behavour, thoughts and talking manners. But even though the decisions of the manager are unfamiliar, the manager knows exactly that there are certain decisions anyway. Mostly these decisions manifest that these decisions belong to the personality, or they belong to both the personality and the society. But one truth should not be neglected that, at first the man manifests not the interest in another person or the society, but the interest in himself, his own personality. In other words, the attention he pays for himselfis much more than he pays for the other people. Deil Carnegi mentioned that the social views of the people are established on the basis of the private interests, whatever background the prominent people have, they are always popular among the people, they will always try to surprise the world, people and they wil try to be remembered even after they die, they do everything to deserve it [5, p. 43], S. Parkinson, M. Roostomji claim that every person has a target, people spend their life on fulfilling an achieving this target all the time [6, p. 6-7]. And the politician F. Ravshanov expressed their opinions saying "as this target can be achieved through relationships with people around, people will help to implement these plans, and they work out several interests for themselves, they are applied in different ways, these people will try to gather some people having the same opinions and viewpoints [7, p. 223-224].

There is one more method of utilizing the individuality of taking care of own life for the person in terms of the attitude in management. A skilled manager is more likely to know that the people like more to hear pleasant compliments about themselves rather than discussing some issues. Because people want the other people to know about them many things. These days many managers are distinguished with less ability to influence on the other people, because most of them are occupied in their own plans, implementing and the ways to solve the problems. The fact that the manager doesn't know that the work he does will decide the future of many people and that he can not realize social importance 
of the work is the main factor which can slow down the development [8, p. 222-246].

Most managers are not able to start effective relationships with colleagues and they may even then do the things which can help them to achieve their goals but which can also hinder the others, and they will try to hide what wrong they have done. This sort of relations in management can lead to worsening consequences in growth of detriment to social and spiritual being of the society or the organization, and even this attitude can turn into ordinary situation for the future generations.

Transformation into democratic and market relations in Uzbekistan requires to get effective use of the new forms, traditional methods of education and training of the management professionals. Besides utilizing important and effective measures and experience which can meet the world standards can also be useful to accomplish all the tasks of establishing democratic society for educating the managers of high standard education. This has social and political importance [9, p. 31].

Influencing on the people in management is the main target of this sector. To obligate somebody to do something a manager should have a reason that prompts the employee to feel that it is beneficial for him, then he can accomplish this task in accordance with the plan made. Prompting the man to live in the right way, a man should urge himself to make the right plans, to make good impression on people about himself.

To obligate the employees to do a certain task voluntarily and with the utmost discretion is a very complicated issue. At first the manager should make sure that all the opinions, comments and the proofs the partner is telling are sincere and close to reality. The manager can succeed only in case he makes the employees voluntarily work, accomplish tasksm not with obligation $[10$, p. 136]. The employee working for the government should pay much attention to the following technologies of attitude which can give positive re- sults, in this case he can make progress in his activity:

1. A manager should know how to explain the employees that it is important to work with him in cooperation, to make the others think similar to himself. Only the manager can cause different opinions, rumours to appear about himself. If the results of the work are going to be useful for just a manager, and if they are useless or neutral for the others, then, the manager I thought to have made a big mistake. This eventually leads the manager to lose trust, respect of the other people, and it prompts indifferent attitude and lack of responsibility to seem ordinary situation for the employees.

2. While urging the employees to do tasks voluntarily, the manager should explain what the benefit of this task consist of, and the employees should make sure about that [11, p. 69]. When there are comments serving for these targets and interests, the people will start feeling convinced, thinking positively and following the commitments.

The manager can even behave in a way that could lead nine people out of ten to have positive opinion about him. While implementing this, the following requirements should be kept in mind:

- firstly, the first minute of each conversation can decide what the result can be in this case. Here glance, voice, tone, the manners of speech, the attitude, the clothes, personal appearance, behavior and many other principles can be very important;

- secondly, the second main law of the human behavior is that people will react with very strong social emotions to behavior of others (in other words, a human has social feeling).A manager should manifest not his own interests for other people, but he needs to manifest them his own interest in other people. If people realize that they are working in accordance with interest and benefits of the manager, they will try to avoid him, they will not try to follow him, but if they feel that the manager is working for their benefit, then they will try to cooperate with him. 
To sum up all the cultural and historical traditions had individual peculiarities up to the 19 century. In the second $50 \mathrm{~s}$ of this century, as soon as central Asia was invaded and surrendered by Russia, not only Russian, but western culture also started affecting the continent and the society. The way that they lived with the local population caused the local people to have changes in their lifestyle and behavior during 150 years. Taking this into account it is also possible to say that the character of the current generation has aspects of the modern western traditions and those of the ancient east. This of course makes the manager responsible and requires him to know all the aspects of the western modern and eastern ancient traditions such as lifestyle and behavior [12, p. 22].

In this way we preferred to mention about some important peculiarties of the methods of the modern management technology which should be complied with by the modern employee hired by the government. The fact that the manager has these individual peculiarities and that all the staff members and other people confirm and admit this will specifically raise the reputation of the manager; provides development of the organization; has positive influence on education of the young generation; brings benefits in favour of the society; develops the compliance of the rules and disciplines of labour; creates opportunities to reduce crimes in number; prompts the society to get united; prompts different positive individual peculiarities to be formed.

\section{Bibliography}

1. Mirziyoev Sh. Critical analysis, strong discipline and personal responsibility - should be each officials' daily rule. - T. : Uzbekistan. 2017. Page 6. www.lex.uz

2. Karimov I. A.Uzbekistan is on the threshold of the 21 century. - T. : Uzbekistan, 1999. - p. 15-16.

3. Nazarov Q., Ergashev I. And many others. Nationalidea and the responsibility of the administrator. - T. : NMIU named after G. Gulom. 2007. $226 \mathrm{p}$.

4. The order PO-5185 of the president of the republic of Uzbekistan "The conception about ratifying administrative reforms in the republic of Uzbekistan" September 8, 2017. www.lex.uz.

5. Carnegi D. How to attract friends and influence on the people. - T. : Shark, 1992. - P. 43.

6. Parkinson S. N., Roostomji K. Art of the management. - Moscow : Farm-Press, 2001. P. 6-7.

7. Ravshanov F. National studies of management: history and experience. - T. : Academia, 2007. P. 223- 224.

8. Ravshanov F. National studies of management: history and experience. - T. : Academia, 2007. P. 222-246.

9. Kuranbayev K. The system of the government administration: problems of formation and development (political and social features). Dissertation written to be nominated with the scientific degree of doctor of political sciences. - T., 2008. - $31 \mathrm{p}$.

10. Holbekov A., Jumayev R., Umarova N. and many others. Social and political principles of management. - T. : NMIU named after Gafur Gulom, 2008. - $136 \mathrm{p}$.

11. Ravshanov F. National studies of management: history and experience. - T. : Academia, 2007. $69 \mathrm{p}$.

12. Kuronov M. Character of Uzbek nationality and national idea. - T. : Ma'naviyat, 2005. - 96 p. P. 22.

(c) Yusubov J. K., 2017. 